\title{
Sugarcane Bagasse Saccharification by Enzymatic Hydrolysis Using Endocellulase and $\beta$-glucosidase Immobilized on Different Supports
}

\author{
Wilson G. Morais Junior ${ }^{1, *}$, Thályta F. Pacheco ${ }^{2}$, Shipeng Gao ${ }^{3}$, Pedro A. Martins ${ }^{3}{ }^{\circledR}$, José M. Guisán ${ }^{3}(\mathbb{C}$ and \\ Nídia S. Caetano ${ }^{1,4}$ (D) \\ 1 CIETI, School of Engineering (ISEP), Polytechnic of Porto (P.Porto), R. Dr. António Bernardino de Almeida, \\ 4249-015 Porto, Portugal; nsc@isep.ipp.pt \\ 2 EMBRAPA Agroenergy, Parque Estação Biológica, 70770-901 Brasília, Brasil; thalyta.pacheco@embrapa.br \\ 3 Departamento de Biocatálisis, Instituto de Catálisis y Petroleoquímica (CSIC), Calle Marie Curie, \\ 28049 Madrid, Spain; spgao9276@gmail.com (S.G.); pedropam.bio@gmail.com (P.A.M.); \\ jmguisan@icp.csic.es (J.M.G.) \\ 4 LEPABE-Laboratory for Process Engineering, Environment, Biotechnology and Energy, Faculty of \\ Engineering of University of Porto (FEUP), R. Dr. Roberto Frias, 4200-465 Porto, Portugal \\ * Correspondence: wgdmj@isep.ipp.pt
}

check for updates

Citation: Morais Junior, W.G.; Pacheco, T.F.; Gao, S.; Martins, P.A.; Guisán, J.M.; Caetano, N.S. Sugarcane Bagasse Saccharification by Enzymatic Hydrolysis Using Endocellulase and $\beta$-glucosidase Immobilized on Different Supports. Catalysts 2021, 11, 340. https:// doi.org/10.3390/catal11030340

Academic Editor: Francisco Plou

Received: 18 February 2021

Accepted: 4 March 2021

Published: 7 March 2021

Publisher's Note: MDPI stays neutral with regard to jurisdictional claims in published maps and institutional affiliations.

Copyright: (c) 2021 by the authors. Licensee MDPI, Basel, Switzerland. This article is an open access article distributed under the terms and conditions of the Creative Commons Attribution (CC BY) license (https:/ / creativecommons.org/licenses/by/ $4.0 /)$.

\begin{abstract}
The saccharification of sugarcane bagasse by enzymatic hydrolysis is one of the most promising processes for obtaining fermentable sugar to be used in the production of secondgeneration ethanol. The objective of this work was to study the immobilization and stabilization of two commercial enzymes: Endocellulase (E-CELBA) in dextran coated iron oxide magnetic nanoparticles activated with aldehyde groups (DIOMNP) and $\beta$-glucosidase (E-BGOSPC) in glyoxyl agarose (GLA) so that their immobilized derivatives could be applied in the saccharification of pretreated sugarcane bagasse. This was the first time that the pretreated sugarcane bagasse was saccharified by cascade reaction using a endocellulase immobilized on dextran coated $\mathrm{Fe}_{2} \mathrm{O}_{3}$ with aldehyde groups combined with a $\beta$-glucosidase immobilized on glyoxyl agarose. Both enzymes were successfully immobilized (more than $60 \%$ after reduction with sodium borohydride) and presented higher thermal stability than free enzymes at 60,70 , and $80^{\circ} \mathrm{C}$. The enzymatic hydrolysis of the sugarcane bagasse was carried out with $15 \mathrm{U}$ of each enzyme per gram of bagasse in a solid-liquid ratio of 1:20 for $48 \mathrm{~h}$ at $50{ }^{\circ} \mathrm{C}$. Under these conditions, $39.06 \pm 1.18 \%$ of the cellulose present in the pretreated bagasse was hydrolyzed, producing $14.11 \pm 0.47 \mathrm{~g} / \mathrm{L}$ of reducing sugars ( $94.54 \%$ glucose). In addition, DIOMNP endo-cellulase derivative maintained $61.40 \pm 1.17 \%$ of its enzymatic activity after seven reuse cycles, and GLA $\beta$-glucosidase derivative maintained up to $58.20 \pm 1.55 \%$ of its enzymatic activity after nine reuse cycles.
\end{abstract}

Keywords: endocellulase; immobilization; saccharification; sugarcane bagasse; $\beta$-glucosidase

\section{Introduction}

In recent years, due to the shortage of non-renewable energy resources and increasing environmental pressure from greenhouse gases released by burning of fossil fuels, there has been an increase in the number of studies searching for alternative production of cleaner fuels compared to petroleum-based fuels. Second-generation biofuels are produced from lignocellulosic biomass from agricultural and forestry residues, which are considered bountiful sources that neither compete with food requirements nor impact the food and feed markets [1]. Sugarcane bagasse is one of the most abundant and promising biomass sources in the world, obtained from the processing of sugarcane with an estimated global yield of 510.3 million tons per year [2].

Sugarcane bagasse is predominantly composed of cellulose, hemicellulose, and lignin, which are strongly associated to form the plant cell wall, resulting in a stable and recalci- 
trant structure [3]. Cellulose and hemicellulose are polysaccharides that cannot be directly converted into ethanol but can be hydrolyzed to obtain monosaccharides such as glucose and xylose that, in turn, can be fermented to produce ethanol $[4,5]$. Enzymatic hydrolysis is applied to convert cellulose to glucose (substrate used in the classic production of first-generation ethanol) [6]. Once pre-treated, lignocellulosic biomass presents less hemicellulose and lignin, which makes cellulose more accessible to enzymes, increasing the hydrolysis efficiency $[7,8]$.

Recently, many studies have reported the use of different combinations of enzymes and enzymatic cocktails composed of three or more enzymes [9-13]. Endoglucanase (EC 3.2.1.4) in synergy with $\beta$-glucosidase (EC 3.2.1.21) are commonly used in enzymatic hydrolysis of pretreated lignocellulosic biomass, due to their combined action: Endoglucanases catalyze the hydrolysis of cellulose to cellobiose, which then serves as substrate for glucose production by the action of $\beta$-glucosidases $[12,14,15]$.

The pretreated sugarcane bagasse saccharification by enzymatic hydrolysis is an expensive process mostly due to the cost of the applied enzymes, whereby the reuse of these biocatalysts is an interesting means to reduce this cost. For years, several enzymatic immobilization techniques have been used with well-established protocols in order to enable not only the reuse of these biocatalysts, but also to improve their activity and stability, to prevent enzymes from aggregating and undergoing autolysis, and to increase flexibility of the reactor design [16,17].

It is possible to immobilize two or more enzymes on the same support forming a multienzymatic system to be applied in cascade reactions. A disadvantage of this immobilization method is that the immobilized derivative can only be applied to the same reaction and, if the enzymes have different stability, the derivative loses efficiency with the loss of activity of at least one of the enzymes [18]. Thus, the supports used to immobilize each enzyme must be chosen considering both the material (porous or non-porous) and the recovery method at the end of each reaction cycle. Using endocellulases and $\beta$-glucosidases as catalysts in hydrolysis, the first enzyme must not be immobilized in porous supports because it will not be able to access the insoluble substrate (cellulose), unlike the second enzyme that hydrolyzes a soluble substrate (cellobiose) [19].

Among the several existing enzyme immobilization protocols, the method performed by multipoint covalent link on activated supports has been reported as the most promising to improve the stability of the catalyst since, once immobilized, the links between the active groups of the support and the enzyme are maintained providing resistance to any conformational change [17]. In this context, glyoxyl agarose is considered one of the most suitable supports providing higher stability to the immobilized enzyme, allowing a recovery of activity between 60 and 100\% [20].

Immobilization techniques using magnetic nanoparticles as non-porous support have attracted much attention due to properties such as cost and ease in the synthesis of the support [21], better enzyme performance by biocompatibility, high surface area availability, and the simplicity of recovery using an external magnetic field [22], which can increase the recycling of both the support and the immobilized derivative [23].

Thus, this study aims to immobilize an endocellulase and a $\beta$-glucosidase (both commercial) on different supports, respectively. Dextran coated $\mathrm{Fe}_{2} \mathrm{O}_{3}$ with aldehyde groups were used as a non-porous support to immobilize endocellulase and $\beta$-glucosidase was immobilized on glyoxyl agarose. The derivatives were characterized concerning thermal stability and applied in saccharification of pretreated sugarcane bagasse to obtain a glucose-rich hydrolyzate. For the first time, endocellulase was immobilized on the nonporous support dextran coated $\mathrm{Fe}_{2} \mathrm{O}_{3}$ with aldehyde groups, to be applied in combination with a $\beta$-glucosidase immobilized on glyoxyl agarose for sugarcane bagasse saccharification by cascade reaction. 


\section{Results and Discussion}

\subsection{Immobilization of Endocellulase and $\beta$-Glucosidase on Different Supports}

Initially, a load of $35 \mathrm{U} / \mathrm{g}$ of support (E-CELBA) and $30.67 \mathrm{U} / \mathrm{g}$ of support (E-BGOSPC) were used for immobilization. The immobilization was carried out in glyoxyl agarose at $\mathrm{pH} 10.0$ and room temperature. Immobilization times of 1, 2, and $4 \mathrm{~h}$ of incubation were evaluated and after each time, Schiff bases were reduced to form covalent bonds and to ensure that the remaining aldehyde groups of the support were converted to hydroxyls [24].

Table 1 shows the results of immobilization yield and specific activity before and after the reduction with $\mathrm{NaBH}_{4}$ for 1, 2, and $4 \mathrm{~h}$ of immobilization of each enzyme at room temperature. Almost $90 \%$ of E-CELBA was immobilized on dextran coated iron oxide magnetic nanoparticles (DIOMP) in the first hour, but after reduction, the derivative presents only $37.7 \%$ of immobilized activity representing $11.72 \pm 0.21 \mathrm{U} / \mathrm{g}$ of support. With $2 \mathrm{~h}$ of incubation, $97.76 \pm 2.21 \%$ of the enzyme was immobilized with $51.4 \%$ activity loss after reduction. However, after $4 \mathrm{~h}$ of incubation, $96.56 \pm 3.40 \%$ of E-CELBA was immobilized retaining $65.21 \%$ of its activity $(22.04 \pm 0.42 \mathrm{U} / \mathrm{g}$ of support) after the reduction. The difference in enzymes activity after reduction, at different immobilization times, could be explained by the change in type of enzyme-support interaction over time. At the beginning of immobilization on supports activated with aldehyde groups, although the first bonds between the aldehyde group and primary amino groups of the enzyme are made quickly, they are weak and can be broken making them reversible; over time, additional bonds are made, increasing the quantity of bonds between the enzyme and support, leaving its structure more rigid, resulting in stability gains to the immobilized derivative $[20,25]$.

Table 1. Effect of immobilization time on different supports and reduction with $\mathrm{NaBH}_{4}$ on enzyme activity, $\mathrm{pH} 10.0$, at room temperature.

\begin{tabular}{ccccccc}
\hline \multirow{2}{*}{ Enzyme } & \multirow{2}{*}{ Support } & \multirow{2}{*}{ Immobilization Time (h) } & \multicolumn{2}{c}{ \% Immobilization } & \multicolumn{2}{c}{ Specific Activity (U/g Support) } \\
\cline { 3 - 6 } & & & Before $^{\mathbf{1}}$ & After $^{\mathbf{1}}$ & Before $^{\mathbf{2}}$ & After $^{2}$ \\
\hline \multirow{3}{*}{ E-CELBA } & \multirow{2}{*}{ DIOMNP } & 2.0 & $88.82 \pm 1.32$ & $33.49 \pm 0.61$ & $31.09 \pm 0.46$ & $11.72 \pm 0.21$ \\
& & 4.0 & $97.76 \pm 2.21$ & $47.51 \pm 1.07$ & $34.22 \pm 0.77$ & $16.63 \pm 0.37$ \\
& & 1.0 & $96.56 \pm 3.40$ & $62.97 \pm 0.45$ & $33.80 \pm 1.19$ & $22.04 \pm 0.42$ \\
\hline \multirow{2}{*}{ E-BGOSPC } & \multirow{2}{*}{ GLA } & 2.0 & $2.09 \pm 0.48$ & $0.31 \pm 0.03$ & $0.64 \pm 0.15$ & $0.10 \pm 0.01$ \\
& & 4.0 & $6.95 \pm 1.66$ & $1.75 \pm 0.16$ & $2.13 \pm 0.51$ & $0.54 \pm 0.05$ \\
\hline
\end{tabular}

1,2 Values referring to \% immobilization and specific activity before and after reduction with $\mathrm{NaBH}_{4}$.

Results of E-BGOSPC immobilization on GLA were not as expressive as for endocellulase, obtaining an immobilization of only $13.71 \pm 1.12 \%$ and $3.16 \pm 0.11 \%$ after the reduction (Table 1). On the other hand, E-BGOSPC presents lower stability in alkaline $\mathrm{pH}$ (manufacturer's information), which may have interfered during the immobilization process. An enzyme immobilization hardly occurs at slightly alkaline $\mathrm{pH}$ values due to the instability generated by the Schiff bases formation between the enzyme and support. However, in the presence of thiolated compounds (e.g., $N$-acetylcysteine) these bonds are stabilized without irreversible reduction [26]. Thus, in order to decrease the immobilization $\mathrm{pH}$ in GLA $(<9.0)$ without sacrificing support reactivity, $N$-acetylcysteine was used as a pH-reducing agent in the immobilization of E-BGOSPC and the results are shown in Table 2.

In the presence of $50 \mathrm{mM} \mathrm{N}$-acetylcysteine at $\mathrm{pH} 8.5$ and room temperature, in $1 \mathrm{~h}$ of immobilization, more than $50 \%$ of the enzyme was immobilized. After $4 \mathrm{~h} 98.17 \pm 1.12 \%$ of EBGOSPC was immobilized on GLA, maintaining $66.96 \pm 0.76 \%$ of activity $(20.54 \pm 0.28 \mathrm{U} / \mathrm{g}$ of support) after reduction. These results prove that $\mathrm{N}$-acetylcysteine can be used as a $\mathrm{pH}$ reducing agent to improve enzyme immobilization on glyoxyl supports under mild pHs. 
Table 2. Effect of time on immobilization of $\beta$-glucosidase (E-BGOSPC) on glyoxyl agarose and $\mathrm{pH}$-reduction on enzyme activity, $\mathrm{pH} 8.5$, with $\mathrm{N}$-acetylcysteine, at room temperature.

\begin{tabular}{ccccc}
\hline \multirow{2}{*}{ Immobilization Time (h) } & \multicolumn{2}{c}{ \% Immobilization } & \multicolumn{2}{c}{ Specific Activity (U/g Support) } \\
\cline { 2 - 5 } & Before $^{\mathbf{1}}$ & After $^{\mathbf{1}}$ & Before $^{\mathbf{2}}$ & After $^{\mathbf{~}^{2}}$ \\
\hline 1.0 & $50.42 \pm 2.05$ & $23.88 \pm 0.97$ & $15.46 \pm 0.63$ & $7.32 \pm 0.19$ \\
2.0 & $72.57 \pm 1.31$ & $40.80 \pm 0.74$ & $22.26 \pm 0.40$ & $12.51 \pm 0.23$ \\
4.0 & $98.17 \pm 1.12$ & $66.96 \pm 0.76$ & $30.11 \pm 0.34$ & $20.54 \pm 0.28$ \\
\hline
\end{tabular}

1,2 Values referring to $\%$ immobilization and specific activity before and after reduction with $\mathrm{NaBH}_{4}$.

Although immobilized DIOMNP and GLA derivatives showed loss of specific activity after reduction with $\mathrm{NaBH}_{4}$, the results obtained in this work are similar and promising when compared to the results of other works published in the literature. Paz-Cedeno et al. [27] studied the immobilization of endocellulase and $\beta$-glucosidase on graphite oxidemagnetite reaching $63.4 \%$ and $97.2 \%$ of immobilization respectively. Endocellulase from Scytalidium thermophilum and $\beta$-glucosidase from Humicola insolens were immobilized on magnetic nanoparticles with chitosan activated with $\mathrm{NiCl}_{2}$, reaching a $20 \%$ immobilization yield for both enzymes [28]. Nishida et al. [29] studied the immobilization of Aspergillus awamori $\beta$-glucosidase on crosslinked commercial gelatin glutaraldehyde, at $4{ }^{\circ} \mathrm{C}$, reaching $99.8 \%$ immobilization and presenting $62.5 \%$ of the initial enzymatic activity after $2 \mathrm{~h}$ of incubation.

\subsection{Thermal Stability of Soluble Enzymes and Immobilized Derivatives}

Thermal stability tests of both soluble enzymes E-CELBA and E-BGOSPC, and their derivatives immobilized on DIOMNP and GLA, respectively, were carried out in $25 \mathrm{mM}$ sodium phosphate buffer $\mathrm{pH} 5.0$ and 7.0, incubating samples at 60,70 , and $80^{\circ} \mathrm{C}$. Figure 1 shows the results obtained in the experiments.

For all temperatures studied, soluble E-CELBA showed lower stability at $\mathrm{pH}$ 5.0, reaching total inactivation in $6 \mathrm{~h}$ at $60^{\circ} \mathrm{C}$. Whereas, soluble E-BGOSPC, after $72 \mathrm{~h}$ incubated at this temperature, a residual activity of $19.43 \pm 0.86 \%$ was obtained. At temperatures of 70 and $80{ }^{\circ} \mathrm{C}$, both soluble enzymes were completely inactivated in the first $3 \mathrm{~h}$ of incubation. At $\mathrm{pH} 7.0$ and $60^{\circ} \mathrm{C}$, soluble E-BGOSPC was less stable than soluble E-CELBA incubated at $60{ }^{\circ} \mathrm{C}$. At $6 \mathrm{~h}$ incubation, $\beta$-glucanase showed a residual activity of $31.11 \pm 1.08 \%$ with an inactivation of more than $95 \%$ in $24 \mathrm{~h}$, while endocellulase showed $87.05 \pm 1.19 \%$ of residual activity after $6 \mathrm{~h}$ and retained $31.97 \pm 0.99 \%$ of residual activity in $72 \mathrm{~h}$ of incubation. Both enzymes showed similar thermostability at $70{ }^{\circ} \mathrm{C}$ (approximately $50 \%$ inactivation after $4 \mathrm{~h}$ ) and $80^{\circ} \mathrm{C}$ (approximately 50\% inactivation after $2 \mathrm{~h}$ ).

At $60{ }^{\circ} \mathrm{C}$ (Figure 1a), both derivatives showed residual activities superior to $80 \%$ at $72 \mathrm{~h}$ of incubation at both $\mathrm{pH}$ conditions. After $144 \mathrm{~h}$ incubation, DIOMNP derivative remained approximately the $62 \%$ residual activity at $\mathrm{pH} 5.0$ and 7.0. At pH 5.0, GLA derivative was more stable, inactivating approximately $19 \%$ of biocatalyst after $144 \mathrm{~h}$ of incubation.

After $72 \mathrm{~h}$ of incubation at $70{ }^{\circ} \mathrm{C}$ (Figure $1 \mathrm{~b}$ ) and $\mathrm{pH}$ 5.0, both derivatives showed similar stability profiles. DIOMNP derivative lost half of its initial activity in $48 \mathrm{~h}$ incubation at both $\mathrm{pHs}$. The same behavior was observed for GLA derivative incubated at $\mathrm{pH}$ 5.0. On the other hand, when incubated at $\mathrm{pH} 7.0$, GLA derivative lost around $61 \%$ of its activity in $24 \mathrm{~h}$ of incubation.

At $80{ }^{\circ} \mathrm{C}$ (Figure 1c), DIOMNP derivative showed $50.43 \pm 0.78 \%$ of residual activity, while GLA derivative showed $36.48 \pm 0.63 \%$ residual activity in $24 \mathrm{~h}$ of incubation at $\mathrm{pH}$ 5.0. At pH 7.0, DIOMNP was more stable compared to GLA derivative. After 6 h of incubation, DIOMNP derivative maintained $77.37 \pm 1.21 \%$ of initial activity while the GLA derivative maintained only $40.10 \pm 1.09 \%$. Although after $72 \mathrm{~h}$ of incubation at $\mathrm{pH} 5.0$ and 7.0, both derivatives were more than $90 \%$ inactivated, DIOMNP derivative showed residual activity 10-times higher than the GLA derivative at $\mathrm{pH}$ 7.0. 

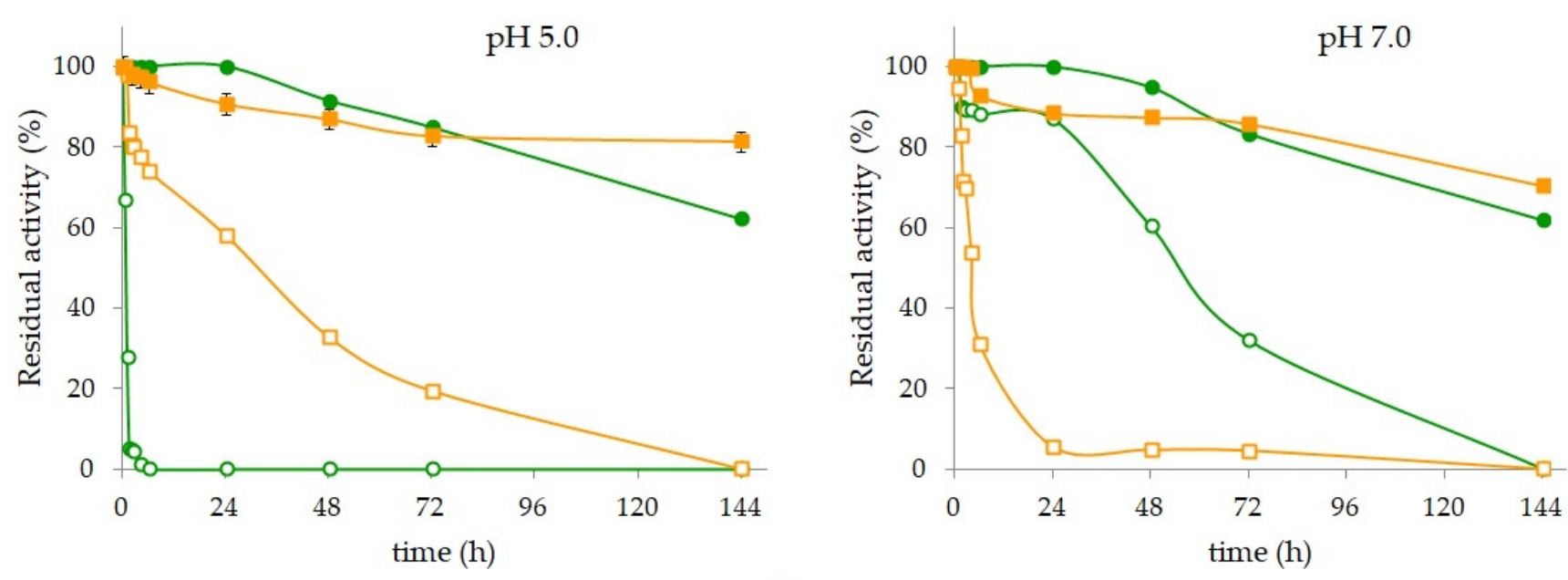

(a)
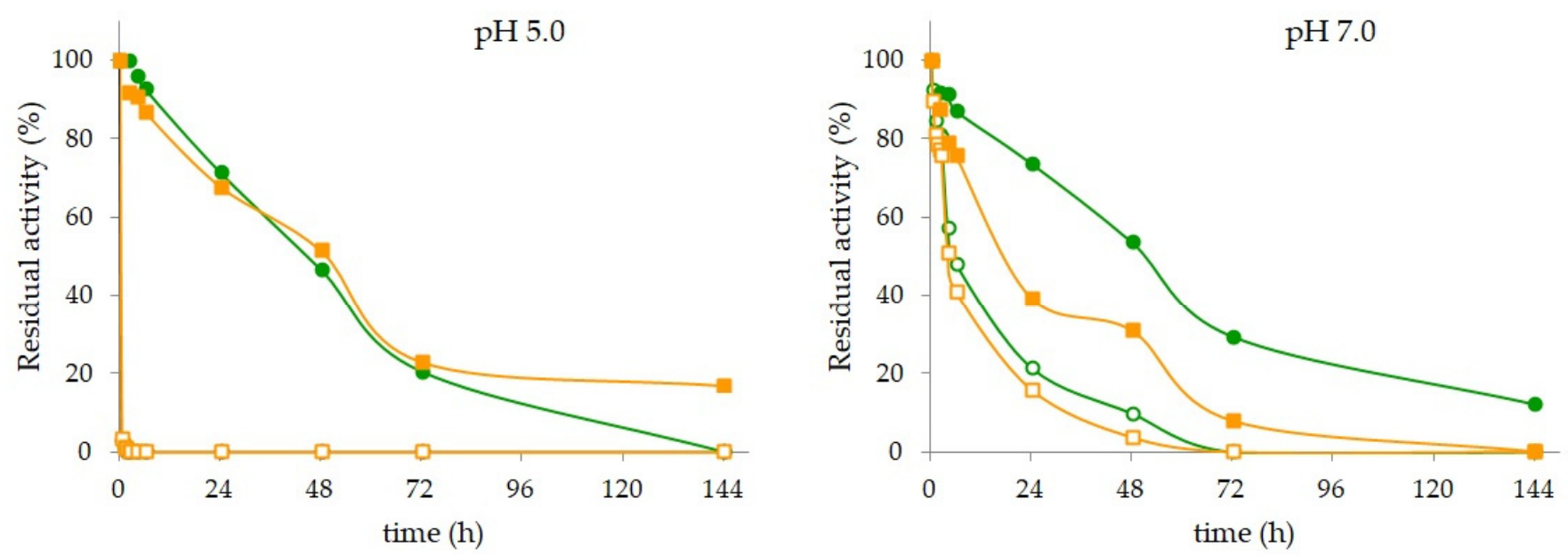

(b)
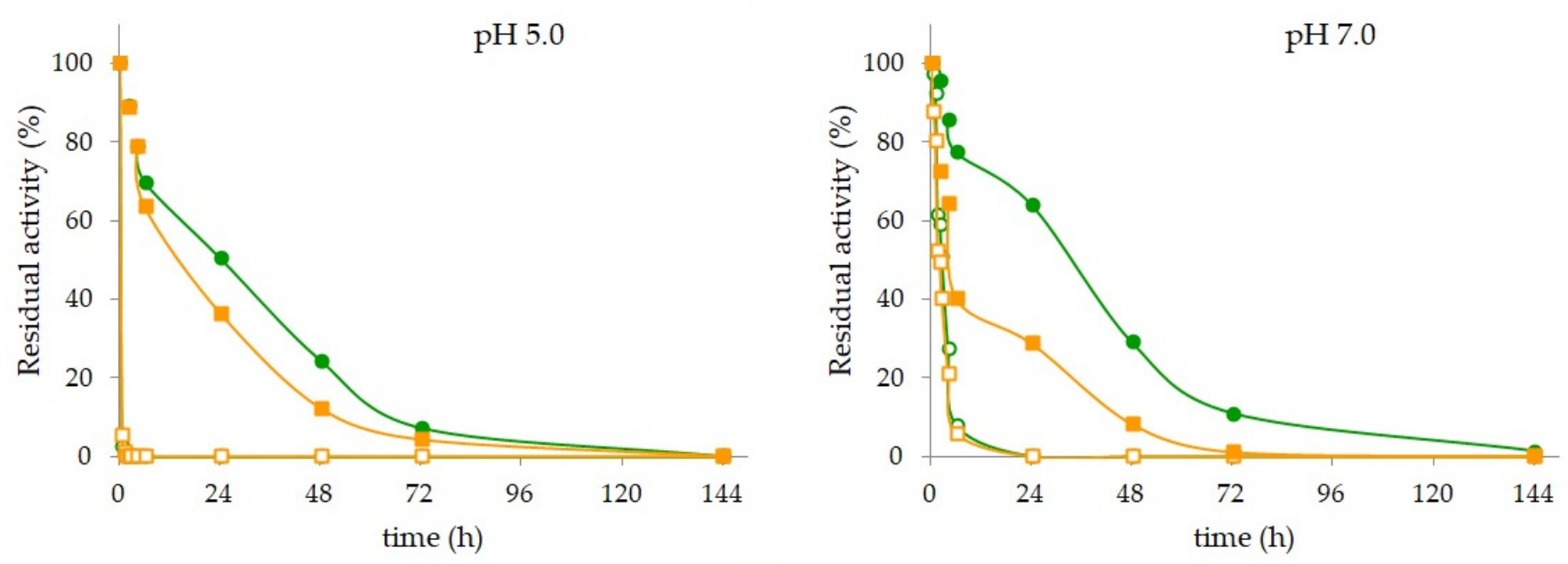

(c)

Figure 1. Thermal stability of soluble enzymes: $(\bigcirc)$ Endocellulase (E-CELBA) and $(\square) \beta$-glucosidase (E-BGOSPC); and derivatives $(\bullet)$ E-CELBA/DIOMNP and (ם) E-BGOSP/GLA. Experiments were carried out in $25 \mathrm{mM}$ sodium phosphate pH 5.0 and 7.0, at (a) $60^{\circ} \mathrm{C}$, (b) $70{ }^{\circ} \mathrm{C}$, and (c) $80^{\circ} \mathrm{C}$.

The results obtained in this study with E-CELBA and E-BGOSPC enzymes show that the enzymatic immobilization significantly improves the thermal stability of obtained biocatalysts. 


\subsection{Saccharification of Sugarcane Bagasse by Enzymatic Hydrolysis}

After immobilization and stabilization of endocellulase in DIOMNP and $\beta$-glycosidase in GLA, the derivatives were applied to saccharification of pretreated sugarcane bagasse to obtain a glucose-rich hydrolyzate, under the conditions described in Section 3.7. Soluble enzymes were applied under the same conditions for control.

After the reaction medium reached the desired temperature, hydrolysis was started by the addition of $0.68 \mathrm{~g}$ of DIOMNP and $0.72 \mathrm{~g}$ of GLA derivatives for each $\mathrm{g}$ of pretreated bagasse. For the control condition, $10.71 \mu \mathrm{L}$ of soluble E-CELBA and $32.61 \mu \mathrm{L}$ of E-BGOSPC were added for each gram of pretreated bagasse.

Table 3 shows the concentrations of sugars present in the hydrolyzate, as well as the cellulose conversions obtained in process catalyzed by derivatives and soluble biocatalysts (calculated according to Equation 1) after $48 \mathrm{~h}$ of reaction.

Table 3. Reducing sugar concentration in hydrolysates and cellulose conversion after enzymatic hydrolysis of sugarcane bagasse.

\begin{tabular}{cccc}
\hline \multirow{2}{*}{ Assay } & \multicolumn{2}{c}{ Sugar Concentration $(\mathrm{g} / \mathrm{L})$} & \multirow{2}{c}{$\begin{array}{c}\text { Cellulose } \\
\text { Conversion (\%) }\end{array}$} \\
\cline { 2 - 3 } & Cellobiose & Glucose & \\
Control & $0.83 \pm 0.05$ & $13.98 \pm 0.49$ & $41.02 \pm 1.32$ \\
Derivatives & $0.77 \pm 0.04$ & $13.34 \pm 0.43$ & $39.07 \pm 1.18$ \\
\hline
\end{tabular}

The control hydrolysis was carried out with soluble E-CELBA and E-BGOSPC, and the hydrolysis with the derivatives DIOMNP and GLA, both with enzymatic activity equivalent to $15 \mathrm{U} / \mathrm{g}$ of bagasse, presented similar results when comparing the concentration of reducing sugars (cellobiose and glucose) and the cellulose conversion.

For the control reaction, $41.02 \pm 1.32 \%$ of the cellulose present in the reaction was converted totalizing $14.81 \pm 0.54 \mathrm{~g} / \mathrm{L}$ of reducing sugars, where $94.40 \%$ was glucose. For the hydrolysis with immobilized derivatives, $13.34 \pm 0.43 \mathrm{~g} / \mathrm{L}$ of glucose were produced ( $94.54 \%$ of the whole amount of reducing sugars), totalizing $14.11 \pm 0.47 \mathrm{~g} / \mathrm{L}$ of reducing sugars produced by converting, approximately, $39.07 \pm 1.18 \%$ of the cellulose present in the reaction. This result was approximately $5 \%$ lower than the amount of reducing sugars achieved in the control hydrolysis catalyzed by soluble enzymes. In both tests, cellobiose concentration was less than $1.0 \mathrm{~g} / \mathrm{L}$ after $48 \mathrm{~h}$, which indicates that the load of E-BGOSPC and its GLA derivative used was adequate to convert cellobiose (released from cellulose by the action of E-CELBA and its derivative DIOMNP) in glucose.

Studies on sugarcane bagasse saccharification by enzymatic hydrolysis have been reported in literature and show promising results. Zhang et al. [30] carried out the hydrolysis of sugarcane bagasse pretreated using $\mathrm{NaOH}$ and ethanol, in an autoclave, and they obtained $88.2 \%$ cellulose conversion into reducing sugars (61.9\% glucose) after $24 \mathrm{~h}$ of reaction. These results were achieved with $40 \mathrm{U}$ of Novozymes soluble active cellulose applied in a reaction medium containing $2.0 \%$ pretreated sugarcane bagasse and supplemented with Tween 80. Mukasuru et al. [11] studied the hydrolysis of sugarcane bagasse pretreated with glycerol in a fed-batch system using a concentration of $3.0 \mathrm{U} / \mathrm{g}$ Cellic CTec 2 cellulose (Novozymes) and accessory enzymes in a medium containing additives such as Tween 80 , tea saponin and BSA, achieving $63.0 \%$ of cellulose conversion with $180 \mathrm{~g} / \mathrm{L}$ of reducing sugars, of which $40 \%$ are glucose. In another study, sugarcane bagasse (pretreated with glycerol) was saccharified using an enzyme cocktail containing cellulases, hemicellulases, and $\beta$-glucosidase from fungus Lichtheimia ramosa and, after $24 \mathrm{~h}$ of reaction, $10.66 \%$ of the cellulose was converted into reducing sugars, of which only $1.45 \mathrm{~g} / \mathrm{L}$ was glucose [31].

The glucose yield and cellulose conversion obtained in the present study are promising and even more effective when compared with other similar works. In order to improve the results obtained, an optimization of the concentrations of E-CELBA and E-BGOSPC immobilized in DIOMNP and GLA, respectively, will be carried out in future work, as well as the solid-liquid ratio to obtain better yields from the conversion of cellulose to glucose. 


\subsection{Derivatives Reuse}

Industrial-scale processes using enzymes are expensive and often economically unviable due to the high cost of these biocatalysts and the impossibility of being reused as they present low stabilities and cannot be recovered. The main advantage of using immobilized enzymes in these processes is the possibility of recovery and reuse the same portion of each biocatalyst in new processes, both in batch and continuous operation. Therefore, the reuse of the derivatives DIOMNP (endocellulase) and GLA ( $\beta$-glycosidase) was studied submitting the derivatives to successive CMC hydrolysis cycles (for $48 \mathrm{~h}$ each cycle) at $50{ }^{\circ} \mathrm{C}$ (Figure 2).

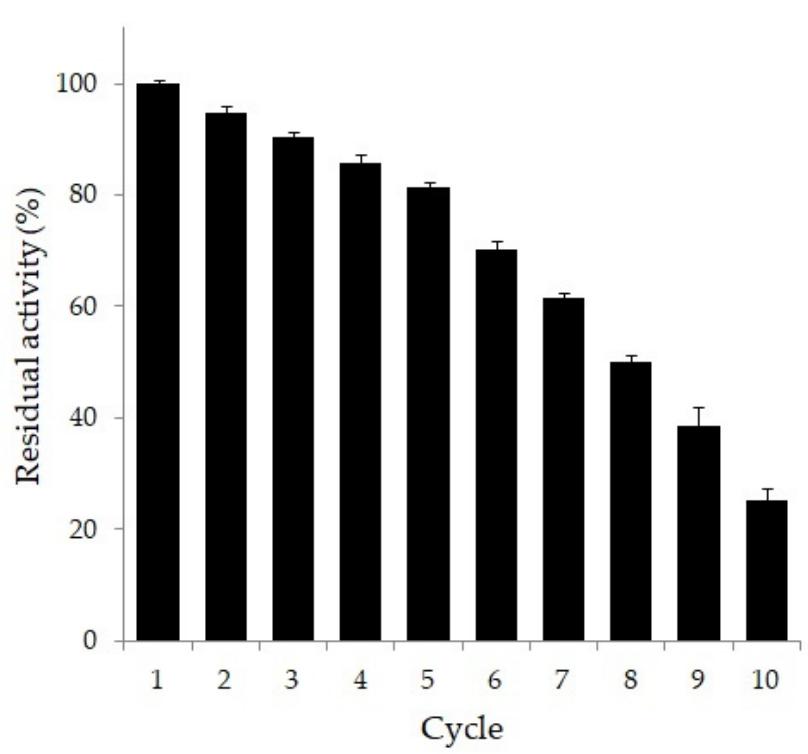

(a)

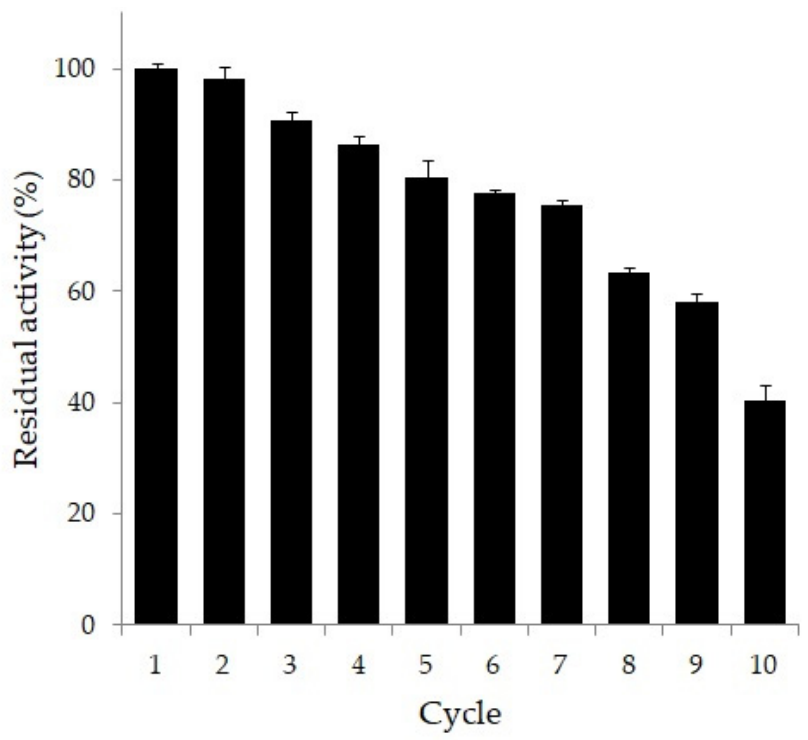

(b)

Figure 2. Reuse of (a) dextran coated iron oxide magnetic nanoparticles (DIOMNP) derivative of endocellulase and (b) Glyoxyl-agarose (GLA) derivatives of $\beta$-glucosidase in consecutive cycles of CMC hydrolysis. Reactions were carried out for $48 \mathrm{~h}$ in $50 \mathrm{mM}$ sodium acetate buffer, $\mathrm{pH} 5.5$, at $50{ }^{\circ} \mathrm{C}$.

The DIOMNP derivative maintained $80 \%$ of its initial activity in the first five cycles (Figure 2a), exhibiting a residual activity of $94.7 \pm 0.71$ and $90.3 \pm 0.93 \%$ in cycles 2 and 3 , respectively. From the cycle 6, DIOMNP showed a marked and constant activity decrease after each subsequent reaction cycle, retaining more than $50 \%$ of the residual activity until cycle 8 , and inactivating almost $75 \%$ after 10 reaction cycles. The GLA derivative presented a similar profile to the DIOMNP derivative in the first five cycles maintaining more than $80 \%$ of its initial activity, with $98.2 \pm 2.27 \%$ and $90.6 \pm 1.65 \%$ of residual activity in cycles 2 and 3, respectively. However, in cycles 6 and 7, the GLA maintained more than $75 \%$ of its initial activity, retaining $58.2 \pm 1.55 \%$ of the residual activity until cycle 9 , and inactivating almost $60 \%$ after 10 reaction cycles. All residual activity values presented by the GLA derivative were higher than those presented by the DIOMNP derivative after each reaction cycle.

Activity losses may be related to the release of enzymes from the supports due to the continuous recovery steps for each of the derivatives and by enzyme inactivation due to the prolonged time of exposure to process parameters such as temperature and $\mathrm{pH}$.

Studies about immobilization of endocellulase and $\beta$-glucosidase on different supports and applying different strategies show the possibility to reuse of immobilized derivatives, conserving between 40 and $90 \%$ of the initial enzymatic activity. Among the several studies reported, recently Paz-Cedeno et al. [27] used graphite oxide-magnetite to immobilize endocellulase and $\beta$-glucosidase resulting in stable derivatives capable of maintaining $70 \%$ and $88 \%$ of their initial enzymatic activities, respectively, after 10 cycles of reuse. Abraham et al. [32] immobilized cellulases on magnetite nanoparticles using glutaraldehyde resulting 
in a stable derivative capable of maintaining $70 \%$ of its initial enzymatic activity after 10 consecutive hydrolysis cycles. On the other hand, $\beta$-glucosidase from Humicola insolens immobilized on magnetic nanoparticles derivatized with chitosan activated with $\mathrm{NiCl}_{2}$, maintained only $50 \%$ of its initial activity after the third cycle of reuse. Endocellulase from Scytalidium thermophilum immobilized on the same support, maintained approximately $45 \%$ of its activity after the second cycle and inactivated $90 \%$ after the fifth cycle [28]. The results presented show that the support and the protocol used in the immobilization can change the way the enzyme is linked on support, resulting in more stable biocatalysts in relation to the reaction parameters, and in order to avoid the release of the enzyme from the support during the recovery steps, thereby increasing the amount of reuse of the derivative.

\section{Materials and Methods}

\subsection{Pretreated Sugarcane Bagasse}

The sugarcane bagasse was kindly provided by sugarcane refinery Jalles Machado S.A, Goiás, Brazil. The bagasse was pretreated with diluted hydrochloric acid $(6.0 \% v / v)$ using $50 \mathrm{~mL}$ of acidic solution for each $3.3 \mathrm{~g}$ of bagasse kept under mild agitation at $96.8^{\circ} \mathrm{C}$ for $375 \mathrm{~min}$. After that, the solid fraction was filtered, washed with distilled water, and delignified with a $\mathrm{NaOH}$ solution $\left(2 \% v / v\right.$ water) in autoclave at $121^{\circ} \mathrm{C}$ for $30 \mathrm{~min}$. Then the resulting solid fraction was filtered, washed with distilled water, and dried. After delignification, the carbohydrate content in the pre-treated sugarcane bagasse was determined according to the NREL procedure [33] presenting a composition as follows: $65.19 \pm 0.68 \%$ cellulose; $2.2 \pm 0.07 \%$ lignin; $21.54 \pm 0.16 \%$ extractives and ashes, $11.03 \pm 0.71 \%$ moisture and absence of hemicellulose.

\subsection{Enzymes}

Endocellulase (endo-1,4- $\beta$-D-glucanase) from Bacillus amyloliquefaciens (E-CELBA) and $\beta$ - glucosidase from Phanerochaete chrysosporium (E-BGOSPC) were purchased from Megazyme Develops, Manufactures \& Supplies Analytical Solutions. According to information provided by the manufacturer, endocellulose and $\beta$-glucosidase activities were $1400 \mathrm{U} / \mathrm{mL}$ and $460 \mathrm{U} / \mathrm{mL}$, respectively.

\subsection{Enzyme Assays \\ 3.3.1. Endocellulase Activity}

E-CELBA activity was determined using carboxymethyl-cellulose (CMC) as the substrate and according to a modified reducing sugar method of analysis [34]. Briefly, $25 \mu \mathrm{L}$ of 1:10 enzymatic solution ( $v / v$ soluble enzyme; $w / v$ immobilized derivative) were added to $50 \mu \mathrm{L}$ of $2 \% \mathrm{CMC}$ solution prepared in $100 \mathrm{mM}$ sodium phosphate buffer $\mathrm{pH}$ 6.0. After $15 \mathrm{~min}$ of reaction at $50{ }^{\circ} \mathrm{C}, 150 \mu \mathrm{L}$ of 3,5-dinitrosalicylic acid (DNS) solution [35] were added and the mixture was boiled for $10 \mathrm{~min}$, cooled, and measured using a spectrophotometer at $540 \mathrm{~nm}$. A unit (U) of enzymatic activity was defined as the amount of enzyme required to produce $1.0 \mu$ mole of reducing sugars per minute, under the assay conditions. A standard calibration curve was defined from serial glucose dilutions.

\subsection{2. $\beta$-Glucosidase Activity}

E-GOSPC activity was analyzed by a method proposed by Hang and Woodams [36] modified using $p$-nitrophenyl- $\beta$-D-glucopyranoside ( $p$ NPG) as the substrate. In $100 \mu \mathrm{L}$ of the 1:10 enzyme solution ( $v / v$ soluble enzyme; $w / v$ immobilized derivative), $90 \mu \mathrm{L}$ of $250 \mathrm{mM}$ sodium citrate buffer $\mathrm{pH} 4.5$ and $10 \mu \mathrm{L}$ of $p \mathrm{NPG}(4.0 \mathrm{mg} / \mathrm{mL})$ were added. After incubation at $37^{\circ} \mathrm{C}$ for $10 \mathrm{~min}, 1.0 \mathrm{~mL}$ of $500 \mathrm{mM}$ sodium carbonate buffer $\mathrm{pH} 10$ was added to stop the reaction. Then the activity was measured by spectrophotometer at $405 \mathrm{~nm}$. A unit (U) of enzymatic activity was defined as the amount of enzyme required for the hydrolysis of $1.0 \mu$ mole of $p$ NP per minute, under the assay conditions, considering $\varepsilon=18,700$. 


\subsection{Support Preparation}

3.4.1. Glyoxyl-Agarose

Glyoxyl-agarose (GLA) support was prepared as described by Guisán [37]. Agarose $(10 \mathrm{BCL})$ activation was carried out by adding $105 \mathrm{~g}$ of washed and filtered agarose in $30 \mathrm{~mL}$ of distilled water and $50 \mathrm{~mL}$ of $1.7 \mathrm{M}$ sodium hydroxide $(\mathrm{NaOH})$ solution containing $1.425 \mathrm{~g}$ of sodium borohydride $\left(\mathrm{NaBH}_{4}\right)$. The solution was kept in an ice bath under magnetic stirring. Then, $36 \mathrm{~mL}$ of glycidol was slowly added and kept under mechanical stirring at room temperature overnight. Sodium periodate $\left(\mathrm{NaIO}_{4}\right)$ was used as oxidizing agent to reduce the hydroxyl groups of glyceryl-agarose (agarose activated with glycidol) into aldehyde groups. To $70 \mathrm{~g}$ of glyceryl-agarose, $25 \mathrm{~mL}$ of $\mathrm{NaIO}_{4}$ were added and the suspension was kept under mild agitation at room temperature for $2 \mathrm{~h}$. Next, the obtained GLA was thoroughly washed with distilled water and filtered.

3.4.2. Dextran Coated Iron Oxide Magnetic nanoparticles Activated with Aldehyde Groups

Magnetic nanoparticles were synthesized using a 4-step protocol with $\mathrm{Fe}_{2} \mathrm{O}_{3}$ as core $(12 \mathrm{~nm})$, coating the surface with dextran from Leuconostoc spp. ( 40 kDa) and activating it to obtain aldehyde functional groups. The magnetic nanoparticles synthesis was carried out following the Massart co-precipitation protocol [38]. An optimized oxidizing treatment using $\mathrm{HNO}_{3}$ was applied in order to improve the magnetic nanoparticles properties and colloidal stability resulting in nanoparticles with a size distribution below $0.2 \mu \mathrm{m}$ of the polydispersity degree [39].

Dextran coating on the nanoparticles surface was performed as described by Bautista et al. [40]. A solution prepared by dropwise addition of $10 \mathrm{~mL}$ of nanoparticles dispersion with $228 \mathrm{mg} \mathrm{Fe}{ }_{2} \mathrm{O}_{3} / \mathrm{mL}$ in $1.6 \mathrm{~mL}$ of $0.8 \mathrm{M} \mathrm{NaOH}$ was mixed with a solution containing $200 \mathrm{mg}$ dextran in $2.5 \mathrm{~mL}$ of $0.5 \mathrm{M} \mathrm{NaOH}$. The mixture was mechanically stirred for $24 \mathrm{~h}$.

The crosslinking step to increase dextran coated nanoparticles stability was carried out using glycidol. For that purpose, $9 \mathrm{~mL}$ of nanoparticle colloid were added to $9 \mathrm{~mL}$ of a $5 \mathrm{M} \mathrm{NaOH}$ solution and $1.5 \mathrm{~mL}$ glycidol ( $96 \%$ solution). The reaction occurred under continuous agitation for $24 \mathrm{~h}$ at room temperature. Then, to remove glycidol excess, the nanoparticles were magnetically separated and dialyzed against deionized water for $24 \mathrm{~h}$.

Finally, to activate the dextran coated magnetic nanoparticles with aldehyde groups, $0.25 \mathrm{~mL}$ of $25 \mathrm{mM} \mathrm{NaIO}_{4}$ was used to oxidize $1 \mathrm{~mL}$ of nanoparticles suspension. The reaction was carried out in the absence of light and oxygen, under mechanical agitation at $150 \mathrm{rpm}$ for $4 \mathrm{~h}$. Then $0.2 \mathrm{~mL}$ of $2 \mathrm{M}$ ethylene glycol was added and left under stirring for $30 \mathrm{~min}$. To remove periodate excess, the nanoparticles were magnetically separated and dialyzed against deionized water for $24 \mathrm{~h}$.

Dextran coated magnetic nanoparticles activated with aldehyde groups (DIOMNP) were stored in distilled water in the concentration of $10 \mathrm{mg}$ DIOMNP/mL.

\subsection{Enzymes Immobilization}

For DIOMNP, before initiating the immobilization, the stock suspension containing the support $(10 \mathrm{mg} / \mathrm{mL})$ was sonicated for $15 \mathrm{~s}$ to undo possible aggregation that may have occurred during storage. Then, $10 \mathrm{~mL}$ of E-CELBA solution diluted 1:400 $(v / v)$ in $25 \mathrm{mM}$ sodium bicarbonate buffer $\mathrm{pH} 10$ were added to $0.5 \mathrm{~mL}$ of support suspension (5.0 mg of DIOMNP). For GLA, $10 \mathrm{~mL}$ of E-BGOSPC solution diluted 1:150 $(v / v)$ in $25 \mathrm{mM}$ sodium bicarbonate $\mathrm{pH} 10$ were added to $1.0 \mathrm{~g}$ of support. Suspensions were left under mild stirring at room temperature. Supernatant and suspension samples were periodically taken and their enzymatic activities were measured. Then, the preparations were washed with distilled water. At $\mathrm{pH}$ 8.5, E-BGOSPC was diluted $(1: 150 \mathrm{v} / \mathrm{v})$ in a solution of $50 \mathrm{mM}$ $\mathrm{N}$-acetylcysteine prepared in $25 \mathrm{mM}$ sodium bicarbonate $\mathrm{pH}$ 8.5. Then, $10 \mathrm{~mL}$ of enzyme solution were added to $1.0 \mathrm{~g}$ of GLA.

After the immobilization of each enzyme on different supports, $\mathrm{NaBH}_{4}$ was used to achieve the final reduction by transforming the remaining aldehydes into inert hydroxyl 
groups and weak Schiff bases into highly stable secondary amino bonds [24]. Thus, $1.0 \mathrm{mg}$ of $\mathrm{NaBH}_{4}$ was added to each $\mathrm{mL}$ of the immobilization suspension and kept under stirring for $30 \mathrm{~min}$ at room temperature. The biocatalysts were vacuum filtered and thoroughly washed with distilled water.

\subsection{Thermal Stability}

According to information provided by the manufacturer, both enzymes are stable at temperatures up to $60^{\circ} \mathrm{C}$. Thus, thermal stability evaluation was carried out by incubating the soluble enzymes and their counterpart derivatives $(1: 400(v / v)$ to soluble endocellulase, 1:150 $(v / v)$ to soluble $\beta$-glucosidase, and 1:10 (w/v) to derivatives diluted in $25 \mathrm{mM}$ sodium phosphate buffer) at 60,70 , and $80^{\circ} \mathrm{C}$, in $\mathrm{pH} \mathrm{pH} 5.0$ and 7.0 for $72 \mathrm{~h}$ and sampling them periodically. Enzymatic activities were determined using the standard assay as previously described. The residual activities were calculated by comparing the final enzymatic activity (after the incubation) to the initial activity (before incubation corresponding 100\%).

\subsection{Saccharification of Pretreated Sugarcane Bagasse}

Saccharification of pretreated sugarcane bagasse was performed with soluble endocellulase and $\beta$-glucosidase (control) and its immobilized derivatives. The reaction was conducted with pretreated bagasse and $100 \mathrm{mM}$ sodium acetate buffer $\mathrm{pH} 5.5$ in a 1:20 liquid-solid ratio. In order to equalize the reaction temperature, the reaction medium was kept under magnetic stirring at $50{ }^{\circ} \mathrm{C}$ for $30 \mathrm{~min}$ before enzyme addition. Then, hydrolysis was initiated with the addition of soluble enzymes or derivatives, both corresponding to $15 \mathrm{U} / \mathrm{g}$ of bagasse. The reaction occurred under mild magnetic stirring at $50^{\circ} \mathrm{C}$ for $48 \mathrm{~h}$. To stop the hydrolysis after the operating time, the reaction mixture with soluble enzymes was kept at $100{ }^{\circ} \mathrm{C}$ for $10 \mathrm{~min}$. In the case of derivatives, hydrolysis was stopped through recovering the catalysts from the reaction mixture either magnetically (for DIOMNP) or by filtration (for GLA). The liquid fraction was analyzed by HPLC coupled with refractive index detector RID 10-A using a reverse-phase column (Aminex ${ }^{\circledR}$ HPX87H). Products were eluted using a solution of $5 \mathrm{mM} \mathrm{H}_{2} \mathrm{SO}_{4}$ as mobile phase at a flow rate of $0.6 \mathrm{~mL} / \mathrm{min}$ and $45^{\circ} \mathrm{C}$. The sugar concentrations were determined using calibration curves.

After quantifying the sugars present in enzymatically saccharified bagasse hydrolyzate, the cellulose conversion $(C c)$ was calculated as described in Equation (1):

$$
\text { Cc }(\%)=\frac{(\text { Cglucose } \times 0.90)+(\text { Ccellobiose } \times 0.95)}{\text { Cbagasse } \times \text { Ccellulose.bagasse }} \times 100
$$

where Cglucose and Ccellobiose are, respectively, glucose and cellobiose concentration $(\mathrm{g} / \mathrm{L})$ in the enzymatic hydrolyzate; 0.9 and 0.95 are stoichiometric factors considering the molecular mass between glucose and cellobiose, respectively; Cbagasse is the concentration $(\mathrm{g} / \mathrm{L})$ of pretreated sugarcane bagasse used in hydrolysis; and Ccellulose.bagasse is the cellulose content $(65.19 \pm 0.68 \%)$ in pretreated sugarcane bagasse.

\subsection{Derivatives Reuse}

Derivatives reuse was performed in batch assays by incubating $0.1 \mathrm{~g}$ of each derivative, with $1.0 \mathrm{~mL}$ of $2 \% \mathrm{CMC}$ prepared with $50 \mathrm{mM}$ sodium acetate buffer $\mathrm{pH} 5.5$ at $50{ }^{\circ} \mathrm{C}$. After complete hydrolysis, DIOMNP derivative was magnetically recovered and the remaining suspension was centrifuged for $1 \mathrm{~min}$ at $3500 \mathrm{rpm}$, to recover the GLA. Then, the hydrolytic activity of derivatives was measured, separately, according to the procedure described in Section 2.3. After each cycle, the derivatives were recovered, washed with $25 \mathrm{mM}$ sodium phosphate buffer $\mathrm{pH} 7.0$, filtrated, and added to a new hydrolysis cycle with a new substrate solution. The activity of each cycle was expressed in relation to the activity after the first cycle (corresponding to $100 \%$ ). 


\section{Conclusions}

In summary, endocellulase immobilized on magnetic nanoparticles and $\beta$-glucosidase immobilized on glyoxyl agarose is a good strategy to reduce costs of the sugarcane bagasse saccharification process in order to obtain a glucose-rich hydrolyzate for ethanol production by submerged fermentation. According to the results presented in this study, the immobilized enzymes E-CELBA and E-BGOSPC had a significant thermal stability improvement. During sugarcane bagasse enzymatic hydrolysis, the results obtained using soluble enzymes and immobilized derivatives were similar, approximately $0.27 \mathrm{~g}$ glucose $/ \mathrm{g}$ bagasse. However, the immobilized derivatives could be used for several consecutive hydrolysis cycles, without significant loss of activity. Specifically, DIOMNP endocellulase derivative maintained more than $60 \%$ of its enzymatic activity in seven reuse cycles, and GLA $\beta$-glucosidase derivative maintained more than $58 \%$ of its enzymatic activity after 8 reuse cycles.

Author Contributions: Conceptualization, W.G.M.J., J.M.G., and N.S.C.; methodology and synthesis, W.G.M.J., S.G., and P.A.M.; physicochemical characterization, investigation, resources, and data curation, W.G.M.J. and T.F.P.; writing—original draft preparation, W.G.M.J.; writing—review and editing, W.G.M.J., T.F.P., S.G., P.A.M., J.M.G., and N.S.C.; supervision, J.M.G. and N.S.C. All authors have read and agreed to the published version of the manuscript.

Funding: This research is part of the project titled ProEMiBiL supported bu European Union's Horizon 2020 funded by Marie Skłodowska-Curie, grant number \#867473. This work was financially supported by Base Funding-UIDB / 04730/2020 of Center for Innovation in Engineering and Industrial Technology, CIETI-funded by national funds through the FCT/MCTES (PIDDAC); Base FundingUIDB/0051/2020 of Laboratory for Process Engineering, Environment, Biotechnology and EnergyLEPABE-funded by National funds through the FCT/MCTES (PIDDAC).

Data Availability Statement: Not applicable.

Acknowledgments: The authors thank sugarcane refinery Jalles Machado S.A for the sugarcane biomass donation; This work was supported by Institute of Catalysis and Petrochemistry (ICP) belonging to the Spanish Council for Scientific Research (CSIC) and Center for Innovation in Engineering and Industrial Technology (CIETI).

Conflicts of Interest: The authors declare no conflict of interest.

\section{References}

1. Rastogi, M.; Shrivastava, S. Recent advances in second generation bioethanol production: An insight to pretreatment, saccharification and fermentation processes. Renew. Sustain. Energy Rev. 2017, 80, 330-340. [CrossRef]

2. Nunes, L.J.R.; Loureiro, L.M.E.F.; Sá, L.C.R.; Silva, H.F.C. Sugarcane Industry Waste Recovery: A Case Study Using Thermochemical Conversion Technologies to Increase Sustainability. Appl. Sci. 2020, 10, 6481. [CrossRef]

3. Jafari, V.; Labafzadeh, S.R.; Jeihanipour, A.; Karimi, K.; Taherzadeh, M.J. Construction and demolition lignocellulosic wastes to bioethanol. Renew. Energy 2011, 36, 2771-2775. [CrossRef]

4. Kang, K.E.; Jeong, J.S.; Kim, Y.; Min, J.; Moon, S.K. Development and economic analysis of bioethanol production facilities using lignocellulosic biomass. J. Biosci. Bioeng. 2019, 128, 475-479. [CrossRef] [PubMed]

5. Guilherme, A.D.A.; Dantas, P.V.F.; Soares, J.C.J.; Dos Santos, E.S.; Fernandes, F.A.N.; De Macedo, G.R. Pretreatments and enzymatic hydrolysis of sugarcane bagasse aiming at the enhancement of the yield of glucose and xylose. Braz. J. Chem. Eng. 2017, 34, 937-947. [CrossRef]

6. Dowe, N. Assessing Cellulase Performance on Pretreated Lignocellulosic Biomass Using Saccharification and Fermentation-Based Protocols. Adv. Struct. Saf. Stud. 2009, 581, 233-245. [CrossRef]

7. Zhao, X.; Song, Y.; Liu, D. Enzymatic hydrolysis and simultaneous saccharification and fermentation of alkali/peracetic acidpretreated sugarcane bagasse for ethanol and 2,3-butanediol production. Enzym. Microb. Technol. 2011, 49, 413-419. [CrossRef]

8. Luo, L.; Van Der Voet, E.; Huppes, G. Biorefining of lignocellulosic feedstock - Technical, economic and environmental considerations. Bioresour. Technol. 2010, 101, 5023-5032. [CrossRef] [PubMed]

9. Sheng, Y.; Lam, S.S.; Wu, Y.; Ge, S.; Wu, J.; Cai, L.; Huang, Z.; Van Le, Q.; Sonne, C.; Xia, C. Enzymatic conversion of pretreated lignocellulosic biomass: A review on influence of structural changes of lignin. Bioresour. Technol. 2020, 324, 124631. [CrossRef]

10. Velasco, J.; Pellegrini, V.D.O.A.; Sepulchro, A.G.V.; Kadowaki, M.A.S.; Santo, M.C.E.; Polikarpov, I.; Segato, F. Comparative analysis of two recombinant LPMOs from Aspergillus fumigatus and their effects on sugarcane bagasse saccharification. Enzym. Microb. Technol. 2021, 144, 109746. [CrossRef] 
11. Mukasekuru, M.R.; Kaneza, P.; Sun, H.; Sun, F.F.; He, J.; Zheng, P. Fed-batch high-solids enzymatic saccharification of lignocellulosic substrates with a combination of additives and accessory enzymes. Ind. Crop. Prod. 2020, 146, 112156. [CrossRef]

12. Hwangbo, M.; Tran, J.L.; Chu, K.H. Effective one-step saccharification of lignocellulosic biomass using magnetite-biocatalysts containing saccharifying enzymes. Sci. Total. Environ. 2019, 647, 806-813. [CrossRef]

13. Guo, H.; Chang, Y.; Lee, D.J. Enzymatic saccharification of lignocellulosic biorefinery: Research focuses. Bioresour. Technol. 2018, 252, 198-215. [CrossRef]

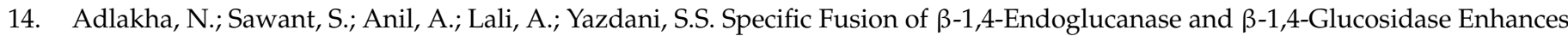
Cellulolytic Activity and Helps in Channeling of Intermediates. Appl. Environ. Microbiol. 2012, 78, 7447-7454. [CrossRef] [PubMed]

15. Dashtban, M.; Maki, M.; Leung, K.T.; Mao, C.; Qin, W. Cellulase activities in biomass conversion: measurement methods and comparison. Crit. Rev. Biotechnol. 2010, 30, 302-309. [CrossRef]

16. Huang, P.J.; Chang, K.L.; Hsieh, J.F.; Chen, S.T. Catalysis of Rice Straw Hydrolysis by the Combination of Immobilized Cellulase fromAspergillus nigeron $\beta-C y c l o d e x t r i n-\mathrm{Fe}_{3} \mathrm{O}_{4}$ Nanoparticles and Ionic Liquid. BioMed. Res. Int. 2015, 2015, 1-9. [CrossRef] [PubMed]

17. Mendes, A.A.; De Castro, H.F.; Giordano, R.L. Covalent attachment of lipases on glyoxyl-agarose beads: Application in fruit flavor and biodiesel synthesis. Int. J. Biol. Macromol. 2014, 70, 78-85. [CrossRef] [PubMed]

18. Ji, Q.; Wang, B.; Tan, J.; Zhu, L.; Li, L. Immobilized multienzymatic systems for catalysis of cascade reactions. Process. Biochem. 2016, 51, 1193-1203. [CrossRef]

19. Siar, E.H.; Zaak, H.; Kornecki, J.F.; Zidoune, M.N.; Barbosa, O.; Fernandez-Lafuente, R. Stabilization of ficin extract by immobilization on glyoxyl agarose. Preliminary characterization of the biocatalyst performance in hydrolysis of proteins. Process. Biochem. 2017, 58, 98-104. [CrossRef]

20. Mateo, C.; Palomo, J.M.; Fuentes, M.; Betancor, L.; Grazu, V.; López-Gallego, F.; Pessela, B.C.; Hidalgo, A.; Fernández-Lorente, G.; Fernández-Lafuente, R.; et al. Glyoxyl agarose: A fully inert and hydrophilic support for immobilization and high stabilization of proteins. Enzym. Microb. Technol. 2006, 39, 274-280. [CrossRef]

21. Esmia, F.; Nematianb, T.; Salehia, Z.; Khodadadi, A.A.; Dalai, A.K. Amine and aldehyde functionalized mesoporous silica on magnetic nanoparticles for enhanced lipase immobilization, biodiesel production, and facile separation. Fuel 2021, $291,120126$. [CrossRef]

22. Liu, R.; Huang, W.; Pan, S.; Li, Y.; Yu, L.; He, D. Covalent immobilization and characterization of penicillin G acylase on magnetic $\mathrm{Fe}_{2} \mathrm{O}_{3} / \mathrm{Fe}_{3} \mathrm{O}_{4}$ heterostructure nanoparticles prepared via a novel solution combustion and gel calcination process. Int. J. Biol. Macromol. 2020, 162, 1587-1596. [CrossRef] [PubMed]

23. Han, J.; Wang, L.; Wang, Y.; Dong, J.; Tang, X.; Ni, L. Preparation and characterization of $\mathrm{Fe}_{3} \mathrm{O}_{4}$-NH2@4-arm-PEG-NH2, a novel magnetic four-arm polymer-nanoparticle composite for cellulase immobilization. Biochem. Eng. J. 2018, 130, 90-98. [CrossRef]

24. Blanco, R.M.; Guisán, J. Stabilization of enzymes by multipoint covalent attachment to agarose-aldehyde gels. Borohydride reduction of trypsin-agarose derivatives. Enzym. Microb. Technol. 1989, 11, 360-366. [CrossRef]

25. Lopes, L.A.; Novelli, P.K.; Fernandez-Lafuente, R.; Tardioli, P.W.; Giordano, R.L.C. Glyoxyl-Activated Agarose as Support for Covalently Link Novo-Pro D: Biocatalysts Performance in the Hydrolysis of Casein. Catalysts 2020, 10, 466. [CrossRef]

26. Bolivar, J.M.; López-Gallego, F.; Godoy, C.; Rodrigues, D.S.; Rodrigues, R.C.; Batalla, P.; Rocha-Martín, J.; Mateo, C.; Giordano, R.L.; Guisán, J.M. The presence of thiolated compounds allows the immobilization of enzymes on glyoxyl agarose at mild pH values: New strategies of stabilization by multipoint covalent attachment. Enzym. Microb. Technol. 2009, 45, 477-483. [CrossRef]

27. Paz-Cedeno, F.R.; Carceller, J.M.; Iborra, S.; Donato, R.K.; Godoy, A.P.; De Paula, A.V.; Monti, R.; Corma, A.; Masarin, F. Magnetic graphene oxide as a platform for the immobilization of cellulases and xylanases: Ultrastructural characterization and assessment of lignocellulosic biomass hydrolysis. Renew. Energy 2021, 164, 491-501. [CrossRef]

28. Carli, S.; Carneiro, L.A.B.D.C.; Ward, R.J.; Meleiro, L.P. Immobilization of a $\beta$-glucosidase and an endoglucanase in ferromagnetic nanoparticles: A study of synergistic effects. Protein Expr. Purif. 2019, 160, 28-35. [CrossRef]

29. Nishida, V.S.; De Oliveira, R.F.; Brugnari, T.; Correa, R.C.G.; Peralta, R.A.; Castoldi, R.; De Souza, C.G.; Bracht, A.; Peralta, R.M. Immobilization of Aspergillus awamori $\beta$-glucosidase on commercial gelatin: An inexpensive and efficient process. Int. J. Biol. Macromol. 2018, 111, 1206-1213. [CrossRef]

30. Zhang, J.; Xie, J.; Zhang, H. Sodium hydroxide catalytic ethanol pretreatment and surfactant on the enzymatic saccharification of sugarcane bagasse. Bioresour. Technol. 2021, 319, 124171. [CrossRef]

31. Garcia, N.F.L.; Santos, F.R.D.S.; Bocchini, D.A.; Da Paz, M.F.; Fonseca, G.G.; Leite, R.S.R. Catalytic properties of cellulases and hemicellulases produced by Lichtheimia ramosa: Potential for sugarcane bagasse saccharification. Ind. Crop. Prod. 2018, 122, 49-56. [CrossRef]

32. E Abraham, R.; Verma, M.L.; Barrow, C.J.; Puri, M. Suitability of magnetic nanoparticle immobilised cellulases in enhancing enzymatic saccharification of pretreated hemp biomass. Biotechnol. Biofuels 2014, 7, 90. [CrossRef]

33. Sluiter, A.; Hames, B.; Ruiz, R.; Scarlata, C.; Sluiter, J.; Templeton, D.; Crocker, D. Laboratory Analytical Procededure (LAP): Determination of Structural Carbohydrates and Lignin in Biomass; Technical Report; National Renewable Energy Laboratory: Golden, CO, USA, 2012; Volume 17.

34. Ghose, T.K. Measurement of cellulase activities. Pure Appl. Chem. 1987, 59, 257-268. [CrossRef]

35. Miller, G.L. Use of Dinitrosalicylic Acid Reagent for Determination of Reducing Sugar. Anal. Chem. 1959, 31, 426-428. [CrossRef] 
36. Hang, Y.; Woodams, E. Apple Pomace: A Potential Substrate for Production of $\beta$-Glucosidase by Aspergillus Foetidus. LWT 1994, 27, 587-589. [CrossRef]

37. Guisán, J. Aldehyde-agarose gels as activated supports for immobilization-stabilization of enzymes. Enzym. Microb. Technol. 1988, 10, 375-382. [CrossRef]

38. Massart, R. Preparation of aqueous magnetic liquids in alkaline and acidic media. IEEE Trans. Magn. 1981, 17, 1247-1248. [CrossRef]

39. Costo, R.; Bello, V.; Robic, C.; Port, M.; Marco, J.F.; Morales, M.P.; Veintemillas-Verdaguer, S. Ultrasmall Iron Oxide Nanoparticles for Biomedical Applications: Improving the Colloidal and Magnetic Properties. Langmuir 2011, 28, 178-185. [CrossRef] [PubMed]

40. Bautista, M.C.; Miguel, O.B.; Zhao, X.; Morales, M.D.P.; González-Carreño, T.; De Alejo, R.P.; Ruiz-Cabello, J.; VeintemillasVerdaguer, S. Comparative study of ferrofluids based on dextran-coated iron oxide and metal nanoparticles for contrast agents in magnetic resonance imaging. Nanotechnology 2004, 15, S154-S159. [CrossRef] 